Revista de
Economild
Contemporâned

Articles

\title{
LENIENCY AND COOPERATION PROGRAMS IN BRAZIL: AN EMPIRICAL ANALYSIS FROM 1994 TO 2014
}

\author{
Fernanda Mariana da Silva Lima ${ }^{a}$ \\ Lucia Helena Salgado ${ }^{b}$ \\ Eduardo Pedral Sampaio Fiuza ${ }^{c}$
}

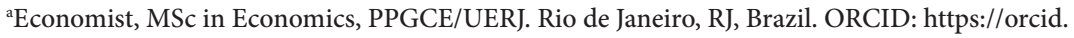 org/0000-0002-7155-9587.

bAssociate Professor at FCE/UERJ and PPGCE/UERJ. Rio de Janeiro, RJ, Brazil. ORCID: https://orcid. org/0000-0001-6538-2626.

'Planning and Research Analyst for IPEA. Rio de Janeiro, RJ, Brazil. ORCID: https://orcid.org/0000-00033278-5538.

Manuscript received on 2018/04/18 and accepted for publication on 2018/12/08.

\begin{abstract}
Leniency and cooperation programs are considered important instruments to assist in the effectiveness of the antitrust policy and they are designed to achieve the following purposes: in the short run to facilitate detection of cartels and in the long run to destabilize existing cartels and deter the appearance of new ones. This study aims to analyze empirically whether the Brazilian leniency program has been delivering these outcomes. To this end, it tests the hypotheses developed by Brenner (2009) to assess the effectiveness of the EU leniency program.
\end{abstract}

KEYWORDS: cartels; antitrust; leniency program; cooperation program; CADE.

JELCODES: D43; L41; C20; C41.

Corresponding author: Fernanda Mariana

Email address: fernandamariana@gmail.com 


\section{OS PROGRAMAS DE LENIÊNCIA E COOPERAÇÃO NO BRASIL: UMA ANÁLISE EMPÍRICA PARA OS ANOS DE 1994 A 2014}

RESUMO: Os programas de leniência e cooperação são considerados ferramentas importantes para auxiliar na efetividade da política de defesa da concorrência e são desenhados para atenderem aos seguintes propósitos: no curto prazo facilitar a detecção de cartéis e no longo prazo desestabilizar cartéis existentes e desincentivar o surgimento de novos. O presente trabalho busca analisar empiricamente se o programa de leniência brasileiro tem atendido a estes propósitos. Para tanto, testaram-se em dados brasileiros as hipóteses desenvolvidas por Brenner (2009) para avaliar a efetividade no programa de leniência da União Europeia.

PALAVRAS-CHAVE: cartéis; defesa da concorrência; programa de leniência; compromisso de cessação; CADE. 


\section{INTRODUCTION}

Cartel is an explicit agreement between competitors to raise prices and/or divide markets, in order to realize profits equivalent to those in a monopoly. In addition to the direct effect of reducing consumer welfare in the form of compulsory price increases, a cartel artificially limits competition between firms and create obstacles to innovation. They do so by discouraging dynamic competition in its production processes and the introduction of new and better products into the market. For all this, cartel has been considered an infringement of the economic order per se in all countries that apply antitrust laws (MATTOS, 2003).

According to a study by the Organization for Economic Cooperation and Development (OECD, 2002) with data collected by the Organization's member countries for the period 1996-2000, it is estimated that cartels generate a significant surcharge (on average of 15 to $20 \%$, being able to reach $50 \%$ or more in some cases), compared to a competitive market, although the surcharge may vary significantly from case to case. In addition, the volume of trade affected by the sixteen largest cartel cases analyzed (one hundred and nineteen cases in total) exceeded the amount of fifty-five billion dollars worldwide, demonstrating the magnitude of cartel in billions of dollars annually.

Over the last decades, competition authorities in several countries have been enhancing their efforts to identify and impose severe administrative and criminal sanctions on cartels. As an example, the European Commission, from 1990 to 2008, imposed penalties for cartel formation that exceeded 13 billion euros, while the United States, from 1997 to 2008, applied criminal penalties in excess of three billion dollars, in addition to other criminal sanctions .

However, it is not an easy task for competition authorities to detect cartels' existence, since it is an illegal activity that needs to be kept hidden and confidential to succeed. To help in this task, leniency programs have been adopted and designed in order to incentive cartel members to report their activity to the authorities, and assist in prosecution of other members in exchange for benefits and amnesties.

In principle, leniency programs are designed to serve two purposes: in the short term, to facilitate the detection of cartels and thereby reduce the cost of enforcement and in the long term to destabilize existing cartels and discourage the emergence of new cartels. In this context, this study aims to evaluate, through an empirical exercise, whether the Brazilian leniency program, complemented by the cooperation program, ${ }^{1}$ fulfills the aforementioned purposes.

1 In the form of termination commitments. 
This paper briefly reviews the literature on the formation of cartels and their impacts on consumer welfare, and the Brazilian experience in deterring this offense. In addition, some theoretical and empirical models are addressed, which sought to study, among other aspects, the efficiency of leniency programs in cartel deterrence. Next, we present the econometric models to answer the research questions, as well as the data used. Finally, the results obtained and the final conclusions of the study are detailed.

\section{LITERATURE REVIEW}

\subsection{HOW CARTELS FORM}

According to Porter (1980 apud MARSHALL and MARX, 2012), five factors (forces) affect the profitability of an oligopolistic industry: extent of interfirm rivalry; existence of barriers to entry; bargaining power of input suppliers; bargaining power of buyers; existence of substitute products. The extent of interfirm rivalry is at the center of these forces and it can be suppressed through collusive actions. These collusive actions increase industry profits and individual firms' profits more quickly compared to the increase in individual firms' profits from their own investments (reduction of production cost, product launch, etc.).

Stigler (1964), in his seminal paper, works with the hypothesis that oligopolists seek collusion to maximize joint profits. Coupled with the desire for profit maximization, firms would need to have certain characteristics, since collusion is more efficient in some circumstances than in others. Even if they have the necessary characteristics to form a cartel, the firms must deal with the problem of monitoring the collusive agreement in order to maintain the sustainability of the cartel.

For Tirole (1988), repeated interactions between oligopolists facilitate collusion. Long-term interactions between the firms of an oligopolistic industry are stimulated by the presence of durable investments, technological know-how and barriers to entry. With the probability of repeated interactions, firms take into account, in addition to the possibility of increasing short-term profits, the possibility of price war and longterm losses when they decide to cut a certain price.

Although collusive actions can increase firms' profits, Motta and Salgado (2015) explain that it is not easy to obtain collusive results, since the participating firms will have incentives to deviate from the collusive action, because in doing so they increase their immediate profits. In other words, the establishment of an agreement is only the beginning of a process, for, even after it has been consummated, the mere fact that there is a price level above the non-cooperative level creates incentives for deviation. 
Therefore, for collusion to occur successfully, it is necessary to have two important elements in the scenario. First, participants should be able to detect deviations appropriately. Second, deviations should be punished. In the presence of a credible threat of punishment, the cartel member is discouraged to deviate from the collusive conduct, because the firm will have to renounce future profits if the cartel firms in fact decide to apply the punishment. This implies that the collusive agreement will only be sustained if firms interact repeatedly on the market, otherwise the punishment will have no effect. For this reason, collusion must be modeled infinitely repeated dynamic games.

Depending on market conditions, reaching an agreement may not be easy. In an environment of uncertainties, agreements must be reviewed frequently, thus increasing negotiation costs. In addition, divergences of perception about future market conditions may hinder firms' understanding, in that they disagree on costs, demand, competitors' entry, among other factors (JACQUEMIN and SLADE, 1989).

According to Motta and Salgado (2015), collusion analysis lies on the ground of the so called 'incentive compatibility constraint', i.e., each firm compares the immediate gain obtained from deviation with the gain to be given up in the future when competitors react through punishments. The firms will choose the collusion strategy only if the former is less than the latter.

\subsection{POLICY OF CARTEL DETERRENCE IN BRAZIL}

The Brazilian antitrust policy was initially disciplined by Law $n^{\circ} 8.884$, dated on June 11,1994 , known as the Competition Law. In the field of prevention and repression of anticompetitive practices, Law $n^{\circ} 8884 / 1994$ was fundamental for the development of antitrust policy. The enforcement of the aforementioned Law, under administrative Law, was carried out by three agencies, which constituted the Brazilian System of Competition Defense (SBDC): the Secretariat of Economic Monitoring (SEAE), the Secretariat of Economic Law (SDE) and the Administrative Council of Economic Defense (CADE). SEAE was responsible for issuing economic opinions on mergers and acquisitions, SDE was responsible for investigating violations of the economic order and CADE was the collegiate that held the final administrative judgment of the cases investigating violations of the economic order (CADE, 2009).

As of the year 2000, important steps had been taken towards improving deterrence of cartels and of other conducts harmful to free competition. In that same year, the SBDC gained two new and fundamental investigation tools: the possibility of conducting dawn raids, and the authority to institute a leniency program (CADE, 2013).

Dawn raids are diligences that require judicial authorization and are performed by surprise at corporate headquarters, business associations or even at executives' home 
addresses, in order to collect key evidence that a cartel exists. Leniency program is an instrument which enables a participant in a cartel to report it to the authorities and assist them in prosecution of other members, in exchange for lenient treatment, such as exemption or reduction of penalties and criminal immunity. In 2003, SDE and the Public Prosecution Office of the State of São Paulo carried out the first dawn raid in cartel investigation in Brazil - in the so-called Crushed Rock Cartel. Also in 2003, the country's first leniency agreement was signed on the occasion of the investigations of the Security Service Providers' Cartel.

The Law no 8884/1994 was amended by Law no 10149/2000, which added articles 35-B and 35-C that allow for leniency agreements with SDE regarding violations of the economic order. According to the Law n ${ }^{\circ} 10149 / 2000$, the leniency agreement would grant total or partial administrative immunity, depending on the authorities' knowledge of the anticompetitive behavior at the time the offense was confessed. If there was no knowledge of it, administrative immunity would be total. If, on the other hand, the conduct was already known, but evidence of it was insufficient, the firm or individual would be granted a reduction of the applicable penalty (one to two thirds), depending on the effectiveness of the cooperation with the authorities that investigated the case. There was also a guarantee of criminal immunity for the directors and administrators of the firm that was the beneficiary of the agreement (CADE, 2009). For the conclusion of a leniency agreement, the applicant was required to comply with the following requirements:

a) Being the first to appear before SDE and to admit participation in the denounced practice;

b) Ceasing the involvement in the denounced practice;

c) Not being the leader of the reported practice;

d) Agreeing to fully cooperate with the investigation;

e) Identifying the other cartel members and hand in evidence of the denounced practice as a result of the cooperation;

f) Lack of sufficient evidence at SDE to ensure the condemnation of the proponent, at the time of the agreement proposition.

Even if a potential candidate did not qualify for an agreement in relation to the particular conduct under investigation (either because they were the second to apply or because they were the leader of the cartel), but did provide relevant information about another cartel, and comply with the other requirements of the Leniency Program, they would receive all the benefits of leniency with respect to the second violation and reduction of one third of the penalty applicable to the first violation. This instrument was given the name of Leniency Plus (CADE, 2009).

In 2011, the Brazilian Antitrust Law was reformulated with the approval of a new law - 12529/2011. As a result, some aspects of the Leniency Program have been changed, such as: 
a) The change of the competent authority: Leniency Agreements were entered into by CADE through the CADE General Superintendency (SG). Prior to the reformulation, this role was performed by the Union, through SDE (which was terminated by law 12529/11).

b) The end of the impediment for the leader of the cartel to be a proponent of the agreement.

c) Extension of the list of crimes directly related to cartel practice, which became the punishability changed by the Agreement signed with CADE. Once the parts abide to the Leniency Agreement, the punishability of the crimes in question is automatically extinguished (CADE, 2016a).

Another important legal instrument that makes up the current Brazilian policy of cartel deterrence is the Cease and Desist Agreements (CDA), which was created by Law $n^{\circ} 8884 / 1994$ and had its penalties applicable to antitrust violations modified by Law no 12529/2011. Unlike the Leniency Agreement, which is an instrument available only to the first offender agent to report the collusive conduct to the antitrust authority and which grants benefits in both administrative and criminal stances, the CDA is accessible to all others investigated in anti-competitive behavior, but grants benefits only under Administrative Law. It constitutes a supplementary mechanism to the leniency program and orders the collaboration process of participating cartel firms in the context of a leniency agreement previously concluded (CADE, 2016b).

The conclusion of a CDA requires compliance with the following requirements:

I) Payment of a monetary contribution to the Defense of Collective Rights Fund, which is established on the grounds of the amount of the expected penalty, from which a percentage reduction is applied that varies according to the following terms:

a) Immediately after the initiation of an administrative procedure and before the case is referred to the CADE Court, the reduction will be:

i) From $30 \%$ to $50 \%$ for the first proponent of CDA;

ii) From $25 \%$ to $40 \%$ for the second proponent of CDA;

iii) Up to $25 \%$ for other CDA proponents;

b) After the documents are sent to the CADE Court, the reduction will be up to $15 \%$.

II) Recognition by the agent of participation in the conduct investigated;

III) Collaboration of the agent with the procedural instruction;

IV) Cessation of involvement in the investigated practice;

V) Payment of a fine in case of non-compliance, total or partial, with the CDA obligations (CADE, 2016b). 
The numbers reflect the success of the instruments (Leniency Program and CDA) in cartel deterrence. Fifty leniency agreements and 14 addendums have been signed since the introduction of the program in 2000 until 2015. Especially in the years 2012-2015, twenty-eight leniency agreements (56\%) and 11 addendums (79\%) were signed, which represents a huge increase in interest in this investigation instrument. In addition, in the same period, more than 100 CDAs were signed with the antitrust authority in anti-cartel cases, 32 of them related to international cartel investigations. Regarding the penalties imposed, the Defense of Collective Rights Fund received more than 500 million BRL in 2015, ten times the amount received in 2012 (FIDELIS and MARTINS, 2016).

According to Fidelis and Martins (2016), some recent experiences and lessons learned by the Brazilian Leniency Program deserve special mention. The first is the increase in the number of cartel cases judged by CADE, including cases arising from Leniency Agreements. The second is the increase in the attractiveness of the Leniency Program related to the use of the Leniency Plus instrument, since after the first case judged by CADE, in which the instrument was used in 2015, the number of firms and individuals seeking the benefit from Leniência Plus has increased. The third is the work that CADE has been carrying out to harmonize the rules of its Leniency Program with other agreements provided for in other laws, such as the recent Law no 12.846/2013, known as the Anti-Corruption Law. The fourth is the improvement of the confidentiality throughout the negotiation of leniency agreements, as well as the special protection of digital evidences. The fifth is the requirement of a high standard evidences for the accomplishment of a Leniency Agreement as a prioritization of 'strong cases', with a more robust probative value vis à vis 'weak cases', in which the evidences of anticompetitive behavior are not enough. The sixth is the increase in cooperation between CADE and the Public Prosecution Offices, which has been generating a better and more coordinated enforcement in cartels deterrence under both administrative and criminal Law, respectively. The last one is the international and national perception of the Brazilian policy regarding cartel deterrence, making evident the fact that, recently, most of the leniency agreements signed by CADE are not derived from investigations of international cartels, which shows that Brazilian society is increasingly aware of CADE's role in deterring cartels, by noting the increased risk of detection by the agency, and they dread severe sanctions, according to Fidelis and Martins (2016).

\subsection{THEORETICAL FRAMEWORK}

As cartels reduce social welfare, they must be fought. However, in most cases, it is difficult to achieve an optimal anti-cartel policy, as they are often secret agreements, making it more expensive to investigate and obtain sufficient evidence for a conviction. 
In this sense, the Leniency Program is an important tool in the cartel deterrence, since it is capable of circumventing the problem of obtaining evidences, increasing the probability of conviction and also stopping the formation of cartels, since it affects the stability of agreements. Not by chance, it has been the object of study over the recent decades. The following is a brief summary of some of these studies that use game theory as the basis for understanding how leniency policies modify competitive and collusive equilibria in infinitely repeated games.

In their seminal paper, Motta and Polo (2003) study, through a dynamic approach, the effects of leniency programs under the incentives of firms to conspire and disclose information that helps antitrust authority to prove unlawful behavior. The authors show that leniency programs help cartel deterrence policies to be more effective only if the antitrust authority has limited resources to detect and investigate cartels, and it is necessary to offer the cartel members an incentive to disclose information about the cartel by reducing penalties. Even in a scenario in which the antitrust authority has sufficient resources to implement a policy capable of inhibiting the formation of cartels, the adoption of leniency programs is not indicated, since the reduction of penalties can be a perverse incentive for the formation of collusion.

For the authors, there are at least two situations in which a cartel member may be led to disclose information. The first is when the probability of cartel detection increases exogenously and the second is when a cartel that has little stability may become unstable after the introduction of a leniency program. The probability of firms disclosing information about cartels increases when penalties are guaranteed even after an investigation has been initiated, which saves resources of the antitrust authority, with consequent increase in welfare. Therefore, allowing penalties only to firms that deviate from the cartel before an investigation is opened is worse than a regime in which firms are entitled to penalties reductions, even after an investigation has been opened. In the optimal scenario, firms that collaborate with the antitrust authority should not pay any fine.

This optimal result was described by Motta and Polo (2003, p. 368-370) through a proposition that describes the optimal combination of policy parameters $(\alpha, p, F, R)$ which implements each of the three possible perfect equilibrium results in sub-games (NC, CR e CNR).

The policy parameters defined by the antitrust authority (AA) are:

a) Probability $\alpha \in[0,1]$ that firms will be investigated by the AA;

b) Probability $p \in[0,1]$ of AA to complete an investigation and condemn the firms;

c) Fine $F \in[0, \mathrm{P}]$ for firms that did not cooperate with AA and which were condemned;

d) Reduced fine $R \in[0, \mathrm{~F}]$ for firms that did cooperate with AA. 
The three possible sub-game perfect equilibrium outcomesin an industry formed by symmetric firms are:

a) NC (No Collusion) - firms choose not to form a cartel;

b) CR (Collude and Reveal) - firms choose to form the cartel and when an investigation is opened they reveal collusion to AA;

c) CNR (Collude and not Reveal) - firms collude, but refuse to disclose any information if an investigation is opened.

The authors verify that the optimal result occurs when $R=0$, for any downward budget constraint available for antitrust policy when firms opt for CR strategy.

Spagnolo (2003) also uses a dynamic model with multiple cartel members to study the best design of a leniency program to prevent the emergence of cartels. The antitrust authority achieves a first-best result by rewarding the first firm to betray the cartel with an amount equal to the sum of the penalties collected from the convicted firms: complete prevention at no cost. In these circumstances, spending resources investigating is sub-optimal. Even though the antitrust authority can not offer positive rewards to firms that deliver cartels, reductions in penalties can be useful as they reduce the cost of such firms to deviate from the collusive arrangement, while at the same time increasing the risk of cartels. The design of an optimal leniency program also suggests that the antitrust authority does not punish firms that have abandoned collusion and rewards only the first firm to denouce the cartel.

Another contribution seeks to study the extent to which leniency programs help deter cartels in phases prior to the opening of an investigation. Ellis and Wilson (2002 apud SPAGNOLO, 2006) highlight an additional reason that may lead cartel members to spontaneously join a leniency program before an investigation is opened. Within Bertrand's dynamic oligopoly model with differentiated products, they show that a leniency program can induce cartel members to betray the cartel to the antitrust authority in order to harm competitors, i.e. increase the (future) marginal costs of rivals through penalties and arrests of managers, thus gaining a profitable strategic advantage in the next competitive phase. On the other hand, the model shows the leniency program has the effect of further stabilizing the cartels because it can be used as a mechanism of punishment to those who deviate from the collusive agreement, making it an ideal instrument to punish deviations if the leniency program is restricted to the first firm to betray the cartel.

Different from the others, Aubert, Kovacic and Rey (2006) propose an antitrust rewards analysis. In their article, they compare the impact of penalty reductions and positive rewards, showing that the latter can deter collusion more effectively than the former, and that rewards for individuals may be more effective than for firms. The model analyzes the benefits and costs of creating an agency problem between firms 
and their employees, allowing the latter to be monetarily rewarded for exposing to Antitrust Authorities the collusive behavior of their firms.

The benefits pointed out by the model are: increasing the cost of maintaining the collusive agreement, since the creation of an agency problem increases the number of potential informants that a collusive firm will have to bribe to keep them silent; and rewards mechanisms for individuals, which tend to be complementary to corporate leniency programs. The above mentioned costs are mainly related to the possible negative effects on internal organization and firm performance (for example: impeding efficient cooperation between firms, restricting information flows among employees, or inducing a more rigid employment structure). By restricting the efficient exchange of information between competing firms, the rewards mechanism is criticized. However, the introduction of penalties for false reports limits the scope of this inefficiency.

The article discusses the intriguing fact that cartel members keep a lot of information about the cartels, at the risk of being detected by the antitrust authorities, and analyzes some explanations. In order to reduce expected penalties, in case the cartel is discovered, firms keep information about the offense; in order to prove to the other cartel members that there was no deviation in the cartel in situations of uncertainty and imperfect information, when the cartel is broken up due to an exogenous shock (e.g. productivity).

\subsection{EMPIRICAL FRAMEWORK}

Empirical work with the objective of verifying the impacts and effectiveness of the leniency programs adopted in the different countries has also been produced more recently. In this context, there are some pitfalls in studying cartels, and perhaps the most critical of them is the potential bias of sample selection because we can only observe the population of detected cartels, since these are illegal agreements and seek to remain secret. In order to circumvent the problem of sample selection bias, theoretical models and discussions have been used to support the development of hypotheses about the behavior of cartels and those involved in collusion after the introduction of the leniency program. Below is a brief summary of some of these empirical works.

Miller has published an important article (2009) in which he investigates the effectiveness of the American leniency program based on an empirical approach. The author has developed a dynamic model of cartel behavior in order to understand how a successful innovation in antitrust policy (such as a leniency program) affects the time 
distribution of the number of cartels discovered. The developed model suggests that an immediate increase in the number of detected cartels is consistent with the hypothesis that a leniency policy increases the probability of cartel detection; and a subsequent decrease in the number of detected cartels below initial levels is consistent with the hypothesis that a leniency policy has a significant deterrent effect, i.e. fewer cartels are formed.

The author uses DOJ data for the period between 1985 and 2005. He noted that there was an increase in the number of cartels detected by the US authorities after the introduction of the new leniency policy which, according to his methodology, is consistent with an increase in the cartel detection rates. He also found that this increase was followed by a drop below the level presented in the periods prior to the implementation of the program, a pattern which, according to his theory, is consistent with the decrease in the cartel formation rate. The changes mentioned in the number of cartels detected were statistically significant.

Brenner (2009) published the first paper that proposes to analyze the effectiveness of the European Leniency Program. His sample consists of 61 cartel cases investigated and prosecuted by the European Commission between 1990 and 2003, which includes the implementation of the first version of the European leniency program, dated on 1996. The author distinguishes between short-term effects of the leniency program associated with disclosure of information and cost reductions for investigation and prosecution - and long-term effects - associated with deterrence of collusive behavior.

Regarding the short-term effects, Brenner suggests that there is an increase in the information disclosed to the antitrust authority in cartel cases in which leniency agreements have been concluded. To test his hypothesis, he uses the total amount of penalties corresponding to a case as proxy for the information disclosed to the authority. In addition, he proposes a reduction of procedural costs in cases that leniency agreements occurred and to test this he uses the duration of investigations as a proxy for costs. The hypotheses are tested by multiple linear regressions and estimated by Ordinary Least Squares (OLS). The author concludes that the evidence suggests that (i) more information is revealed and the legal costs related to investigation and prosecution are lower in the leniency program, and (ii) the duration of investigations in cases in which the leniency agreement exists is reduced by a year and a half on average.

To analyze the long-term effects, Brenner uses the theory developed by Harrington and Chang (2009) and proposes the hypothesis that the average duration of the cartels detected immediately after the adoption of the leniency program is increased. To test it, they make use of a duration model. The last two hypotheses are the same as those developed by Miller (2009). This author concludes that although the European Commission witnessed a sharp increase in the number of convictions after 1996, no evidence was found that cartels became more fragile after the leniency program was adopted. 
Klein (2010) sought to verify the efficiency of leniency programs using data from the 23 OECD countries for the period of 1990 to 2010, and argues that the efficiency of these programs can be derived empirically by analyzing their direct impact on the intensity of competition, considering the hypothesis that a leniency program increases competition in the country and reduces the average profitability of industries. The author used the industry's average profitability to make inferences about the Lerner index or price-cost margin (PCM), which is used as a measure of competition intensity for an industry. To mitigate bias problems of sample selection, endogeneity and omitted variables, he used additional control variables, estimation with instrumental variable and several tests of robustness.

The results indicate a positive impact of leniency programs on intensity of competition, with an approximate decrease of PCM from 3\% to 5\%. By using a widely employed measure for the intensity of competition, the author empirically shows that leniency programs in place lead to increased competition and are therefore an effective tool for destroying or avoiding cartels.

\section{METHODOLOGY}

To evaluate the efficiency of the Brazilian Leniency Program, we use a Brennerbased model (2009). The empirical exercise aims to evaluate the efficiency of the leniency program by answering two questions: (i) Does the leniency program induce a higher level of revealed information about cartels, than the level achieved by traditional methods, and does it consequently decrease the duration and cost of administrative procedures? (ii) Does the leniency program destabilize existing cartels and discourage the emergence of new cartels?

Concerning the first question, leniency programs can be socially desirable as investigations require scarce resources from the agencies, which can be spared by the provision of relevant evidence by cartel members. The second issue, however, concerns the argument that leniency programs can add instability to collusive agreements. They may lead to a situation of prisoners' dilemma among cartel members in a static context leading to an equilibrium outcome, in which cartel members confess their wrongdoings, and they induce existing cartels to disintegrate.

After the implementation of a leniency program, the amount of information disclosed to the antitrust authority is expected to increase. The cost of obtaining this information in the absence of a leniency program would be high (either because of budget constraints of the agency or because the costs of obtaining the information exceed the social benefits of obtaining it). 
As a proxy for information disclosed to the antitrust authority, the total amount of penalties issued in each administrative proceeding will be used. By controlling for other factors that determine the level of penalties, a well documented administrative procedure will result in higher total penalties after implementing the leniency program, than before its implementation. Therefore, it is possible to formulate the following hypothesis:

Hypotesis 1 - The total amount of penalties per administrative proceeding prior to the discounts guaranteed by the leniency program is greater than the total amount of penalties per administrative proceeding prior to the introduction of the leniency program.

In addition, it is possible to use the duration of the investigation as a proxy to infer the costs of investigation and prosecution, making it possible to formulate one more hypothesis:

Hypotesis 2 - After the introduction of the leniency program, the length of the administrative procedure for cartel cases will decrease.

One of the main challenges in measuring the impact of antitrust policy on collusive agreements is that the cartel population is not observable; only the population of detected cartels is observed. To meet this challenge, Harrington and Chang (2009) have developed a model of cartel creation and dissolution to endogenously derive the cartel population and population of discovered cartels and identify how these two populations are related.

The model suggests that, in the absence of leniency programs, there is a kind of 'marginal' industry in which firms are indifferent between colluding or competing with one another because short-term gains to deviate from the cartel and long-term gains from collusion are the same. When leniency programs have a dissuasive impact short-term gains increase or long-term gains decrease, leading the 'marginal' cartel to a set of outcomes of unsustainability.

Harrington and Chang (2009) study in their model the link between the change in detection rate and the duration of the cartels detected before and after the introduction of leniency programs. They find that if these programs have actually been effective in reducing the rate of cartel formation, then we should note a short term increase in the duration of the cartels discovered. This is because 'marginal' cartels disintegrate immediately, and subsequent cartel detections come from a more stable cartel population. Therefore, the following hypothesis is formulated:

Hypotesis 3 - After the introduction of the leniency program, the duration of the detected cartels will increase in the short term.

Miller (2009) develops a dynamic model of cartel behavior from which forecasts derive about the time distribution of the number of cartels detected under a leniency 
regime. It also verifies that a leniency program (or other policy changes) can affect both detection and cartel formation rates. Since a change in detection rate has an immediate effect on the set of detected cartels, while the formation rate changes their number more slowly, the differential effect of the policy can be identified and obtained in the following hypotheses:

Hypotesis $4 \mathbf{a}$ - Since a leniency program increases the detection rate, then the number of detected cartels will increase immediately after the adoption of the program.

Hypotesis $\mathbf{4 b}$ - Since a leniency program sufficiently reduces the formation rate, then the number of detected cartels decrease in the long-term after the adoption of the program.

All four hypotheses presented are the same as those used by Brenner (2009) in his article. To test hypothesis 1 , the following multiple linear regression models will be used:

$$
\begin{gathered}
\ln \left(F_{i}\right)=\alpha_{11}+\alpha_{12} L P_{i}+\alpha_{13} T C C_{i}+\alpha_{14} g\left(D C_{i}\right)+\alpha_{15} h\left(N F_{i}\right)+\alpha_{16} I N D_{i}+\varepsilon_{1 i} \\
\ln \left(R F_{i}\right)=\alpha_{21}+\alpha_{22} L P_{i}+\alpha_{23} T C C_{i}+\alpha_{24} g\left(D C_{i}\right)+\alpha_{25} h\left(N F_{i}\right)+\alpha_{26} I N D_{i}+\varepsilon_{2 i}
\end{gathered}
$$

To estimate the set of equations, the following variables were used:

- $\quad F_{i}$ - Amount of the fine(s) applied by CADE in case $i$, without the discount given to the participant(s) of the Leniency Program;

- $R F_{i}$ - Amount of the fine(s) applied by CADE in case $i$, with the discount given to the participant(s) of the Leniency Program;

- $\quad L P_{i}$ - Case $i$ has (1) or has not (0) some Leniency Agreement;

- $\quad$ TCC - Case $i$ has (1) or has not (0) some Cease and Desist Agreement;

- $\quad D C_{i}-$ Cartel duration (years);

- $\quad N F_{i}$ - Number of cartel firms;

- $I N D_{i}$ - Industry dummy.

Equation (1) seeks to test hypothesis 1 that relates the introduction of the leniency program to an increase in the level of penalties due to the disclosure effects. The dependent variable appears in the equation in its logarithmic form to reduce the effects of the outliers. The variables TCC, DC and NF were included as likely variables in determining the amount of penalties in each case. The effects of $D C$ and $N F$ can be modeled as polynomials to account for their possible non-linear relationships with the dependent variable. For this reason, DC and NF were estimated by a polynomial approximation of second and third degree, according to the significance found. In order to control the specific effects of the industry, the IND variable is included as a proxy for the trade volume affected by the cartel. To verify the equivalence of the $L P$ and TCC variables, since these variables indicate whether or not the cartel deterrence 
instruments are used by the antitrust authority, a coefficient equality test is used, whose null hypothesis is $H_{0}: L P=T C C$. The usual assumptions about least squares estimation are made in providing unbiased and efficient parameters.

In order to verify if the information disclosure effect considered in hypothesis 1 is strong enough to induce an increase in penalties after the adoption of the leniency program, the dependent variable on equation (1) was replaced so that equation (2) was obtained .

Equations (1) and (2) are similar to those used by Brenner (2009) to test hypothesis 1, but there are some differences, namely: in Brenner (2009), the dependent variables were not estimated by the natural logarithm; there are no TCC and NF variables; DC is estimated only at their level (first-degree polynomial); the variable $N C$ (number of countries covered by the cartel) proxies the amount of penalties per case.

To test for hypotheses 2 and 3, duration models will be used. In the analyses of the duration models used in the present work we used the scale factor $\sigma$, which corresponds to $1 / \alpha$ for Weibull distributions and log-logistic, to indicate if a hazard function is monotonically increasing, decreasing or constant.

To test for hypothesis 2 that relates the duration of the administrative procedure to the presence of a leniency program, the following duration model will be used:

$$
\ln \left(D I_{i}\right)=\beta_{11}+\beta_{12} L P_{i}+\beta_{13} D I T C C_{i}+\beta_{14} D C_{i}+\beta_{15} D C_{i}^{2}+\beta_{16} N F_{i}+\beta_{17} I N D_{i}+\varepsilon_{3 i}
$$

In (3), $D I_{i}$ is the duration of investigation procedure (in years), and $D I T C C_{i}$ is the duration of the investigation procedure until the signature of the first CDA (in years).

The variables DITCC, DC and NF were included as probable variables to determine the duration of the administrative procedure in each case. To control the specific effects of the industry, the IND variable was included. A quadratic term for the duration of the cartel is included to account for possible scale effects on the cost function of investigation and prosecution. The error term $\varepsilon$ is an independent random variable and $D I$ follows a Weibull distribution. According to the tests performed, the Weibull distribution presented the best information criteria, thus being preferable to the log-normal and log-logistic distributions.

Several tests were performed to determine the best specification for the TCC variable. Among them, the following explanatory variables were tested: DTCC proportional duration of the administrative procedure until the first $C D A$ was signed; NTCC - number of CDAs by administrative procedure; DESC - discount granted to the signatories of leniency agreements and CDAs (discount on the expected fine). DITCC was also tested as a dependent variable, but the best specification found for the TCC variable was the DITCC variable as an explanatory variable. 
Considering that duration or hazard models are more appropriate to cartel stability, the following model will be used to test hypothesis 3 :

$$
\ln \left(D C_{i}\right)=\beta_{21}+\beta_{22} S R_{i}+\beta_{23} N F_{i}+\beta_{24} I N D_{i}+\varepsilon_{i}
$$

The error term $\varepsilon$ is an independent random variable and $D C$ follows a Weibull distribution. $S R$ is a dummy variable that assumes the value 1 when the cartel is extinguished after the introduction of the leniency program. The industry dummy variables and the number of cartel firms were also identified as variables with a likely impact on cartel stability. According to the log-likelihood criteria, the Weibull distribution presented the largest log-likelihood in relation to the log-normal and loglogistic distributions, whose results were respectively $(-74,29),(-80,48),(-79,75)$.

The differences between equation (4) and the equation used by Brenner (2009) to test hypothesis 3 are that in the latter there is no variable $S R$; also, the proxies used for the duration of the cartel were $L D$ (duration of the cartel after the introduction of the leniency program), LP - ST (dummy value 1 if the cartel is detected during the first 3 years of the leniency program) and $N C$ (number of countries covered by the cartel).

We decided not to use the variable $L D$ in the model of equation (4) because, to make sense, its interpretation should be that the time elapsed until the introduction of the leniency program shall be correlated with the time after the program introduction, which constitutes a reverse causality. In addition, the LP-ST variable was not used either because there seems to be no theoretical support in the hypothesis that the discovery of a cartel during the first three years of a leniency program positively affects the duration of the cartels.

Just like it was done by Brenner (2009), to verify support for hypotheses 4a and 4b, an empirical density plot of the detection frequency over the years will be used, which displays a temporary increase followed by a long-term decrease in the number of detected cartels, thus indicating that the leniency program increases the detection rate and decreases the formation rate.

\section{DATA SOURCE}

The sample is made up of 73 cartel cases investigated and judged by CADE between 1994 and 2016. All information collected is available at CADE's electronic address (www.cade.gov.br), in the session Procedure Search. The sources of information consulted were mainly votes and reports made by the counselor-rapporteurs on administrative proceedings and CDA requirements, SG and SDE reports and rulings. The data collection took quite a long time, since the information searched was not 
always located in the same document standard, which required querying a great number of documents in the same administrative procedure; in addition, many data needed to be estimated as explained below, since they were not explicitly found in the course of the research.

The amounts of penalties charged to firms convicted of cartels, as well as amounts of pecuniary contribution (in cases where CDAs were signed) are expressed in BRL and were updated by the IPCA index, base year 2015 .

In cases in which the documents consulted did not expressly indicate the duration of the cartel, the date when the administrative procedure was opened and the date of the trial respectively were considered as the beginning and the end of the cartel. Table 1 shows some statistics on the cartels that were detected before and after the introduction of the CADE's Leniency Program. After the adoption of the program, it is possible to observe a sharp increase in total penalties, as well as an increase of more than two years on average in the duration of the cartels. The average number of firms in the collusive agreements also increased after the implementation of the program.

Table 1 - Descriptive statistics of cartel cases

\begin{tabular}{lcc}
\hline Period during which the cartel was detected & $\mathbf{1 9 9 4 - 1 9 9 9}$ & $\mathbf{2 0 0 0 - 2 0 1 4}$ \\
\hline Number of cases & 35 & 38 \\
Total penalties in BRL (without discounts) & $279,395,073.83$ & $10,170,808,649.01$ \\
Total penalties in BRL (with discounts) & $279,395,073.83$ & $9,426,903,960.32$ \\
Average duration of cartels (years) & 4.89 & 7.34 \\
Averagenumberoffirms & 2.83 & 4.18 \\
\hline
\end{tabular}

Source: Authors' elaboration based on data from CADE (2016).

Notes: (1) Sum of the penalties without the application of the discounts guaranteed by the leniency agreements with the penalties expected from the cases in which there were signed CDAs.; (2) Sum of the penalties with the discounts guaranteed by the leniency agreements with the monetary contributions of the cases in which the CDAs were signed.

Table 2 shows the T-test of two samples assuming equivalent variances to verify if the average duration of the cartels and the average number of firms before and after the introduction of the Leniency Program are statistically the same. The result shows that in the case of the average duration of the cartels, the hypothesis $H_{0}$ (the averages before and after the introduction of the Program are equal) should be rejected at the 5\% and $10 \%$ levels indicating that, in fact, there was an average increase in duration of the cartels after the introduction of the Leniency Program. However, in the case of the average number of firms, the hypothesis $H_{0}$ should not be rejected, so there is no difference between the averages before and after the introduction of the Leniency Program. 
Table 2 - T-test: two samples assuming equivalent variances

\begin{tabular}{lcccc}
\hline & DC Ante & DC Post & NF Ante & NF Post \\
\hline Average & 4.885714286 & 7.342105263 & 2.828571429 & 4.184210526 \\
Variance & 6.280672269 & 34.71763869 & 18.85210084 & 25.61379801 \\
Observation & 35 & 38 & 35 & 38 \\
Grouped variance & 21.09993646 & & 22.37580218 & \\
Average difference & 0 & & 71 & \\
hypothesis & 71 & & 1.223261111 & \\
Df & 2.282555311 & & 0.112637808 & \\
Stat t & 0.01272729 & & 1.666599658 \\
$P(T<=t)$ one-tailed & 1.666599658 & & 0.225275616 \\
$t$ one-tailed critical & 0.02545458 & & 1.993943368 & \\
$P(T<=t)$ two-tailed & 1.993943368 & & \\
$t$ two-tailed critical & & & \\
\hline
\end{tabular}

Source: Authors' elaboration based on data from CADE (2016).

\section{ANALYSIS OF RESULTS}

To analyze the results, Gretl free software version 1.9.92 was used. As for tables 3 to 6, consider $\left.\left(^{* *}\right) p<0,01 ;{ }^{* *}\right) p<0,05$; and $\left(^{*}\right) p<0,1$. Tables 3 and 4 show respectively the results of equations 1 and 2 .

\section{Table 3 - Model of Equation 1}

\begin{tabular}{|c|c|c|c|c|}
\hline \multicolumn{5}{|c|}{ Result of estimation in OLS, using observations 1-73 } \\
\hline \multicolumn{5}{|c|}{ Dependent variable : 1 _Fi } \\
\hline & coefficient & standard error & t-reason & p-value \\
\hline Const & 12.9621 & 1.13408 & 11.4296 & $6.64 \mathrm{e}-017^{* * *}$ \\
\hline LP & 2.28844 & 0.916649 & 2.4965 & $0.01521^{* *}$ \\
\hline TCC & 0.53639 & 0.724078 & 0.7408 & 0.46162 \\
\hline DC & -0.540541 & 0.388502 & -1.3913 & 0.16909 \\
\hline DC2 & 0.0739388 & 0.0471694 & 1.5675 & 0.12208 \\
\hline DC3 & -0.00245693 & 0.00148163 & -1.6583 & 0.10232 \\
\hline NF & 0.889738 & 0.308438 & 2.8847 & $0.00538^{* * *}$ \\
\hline NF2 & -0.0711999 & 0.0351915 & -2.0232 & $0.04737^{* *}$ \\
\hline NF3 & 0.00173657 & 0.00100725 & 1.7241 & $0.08968^{*}$ \\
\hline SER & -1.57617 & 0.777991 & -2.0259 & $0.04708^{* *}$ \\
\hline IND & 2.9455 & 0.966699 & 3.0470 & $0.00339^{* * *}$ \\
\hline Average dep. variable & \multicolumn{2}{|c|}{13.50679} & variable & 3.299349 \\
\hline Sum of square residuals & \multicolumn{2}{|c|}{217.7309} & egression & 1.873977 \\
\hline R-square & \multicolumn{2}{|c|}{0.722201} & e squared & 0.677394 \\
\hline$F(10,62)$ & \multicolumn{2}{|c|}{16.11828} & lue $(F)$ & $8.52 \mathrm{e}-14$ \\
\hline Likelihood log & \multicolumn{2}{|c|}{-143.4697} & Criteria & 308.9395 \\
\hline
\end{tabular}

Source: Authors' elaboration. 
Table 4 - Model of Equation 2

\begin{tabular}{|c|c|c|c|c|}
\hline \multicolumn{5}{|c|}{ Result of estimation in OLS, using observations 1-73 } \\
\hline \multicolumn{5}{|c|}{ Dependent variable: 1_RFi } \\
\hline & coefficient & standard error & t-reason & p-value \\
\hline Const & 12.9767 & 1.16617 & 11.1277 & $<0.00001^{* * *}$ \\
\hline LP & 1.96145 & 0.942585 & 2.0809 & $0.04158^{* * *}$ \\
\hline TCC & -0.527652 & 0.744566 & -0.7087 & 0.48119 \\
\hline DC & -0.697747 & 0.399494 & -1.7466 & $0.08566^{*}$ \\
\hline DC2 & 0.0896378 & 0.0485041 & 1.8480 & $0.06937^{*}$ \\
\hline DC3 & -0.00283031 & 0.00152356 & -1.8577 & $0.06796^{*}$ \\
\hline NF & 1.06309 & 0.317165 & 3.3518 & $0.00137^{* * *}$ \\
\hline NF2 & -0.0855047 & 0.0361873 & -2.3628 & $0.02129^{* * *}$ \\
\hline NF3 & 0.00205391 & 0.00103575 & 1.9830 & 0.05180 * \\
\hline SER & -1.51132 & 0.800004 & -1.8891 & $0.06355^{*}$ \\
\hline IND & 2.935 & 0.994052 & 2.9526 & $0.00445^{* * *}$ \\
\hline Average dep. variable & & & variable & 3.338130 \\
\hline Sum of square residuals & & & gression & 1.927001 \\
\hline R-square & & & squared & 0.666760 \\
\hline$F(10,62)$ & & & de(F) & $2.22 \mathrm{e}-13$ \\
\hline Likelihood log & & & Criteria & 313.0132 \\
\hline
\end{tabular}

Source: Authors' elaboration.

The estimates of equations 1 and 2 give support to Hypothesis 1, regarding the level of penalties per case after the adoption of the Brazilian Leniency Program. The coefficient of the LP variable is statistically significant at the 5\% and 10\% levels. For Equation 1, the level of penalties in cases with leniency agreement was $228.84 \%$ higher than cases without agreement. For Equation 2, the level of penalties in leniency cases was 196.14\% higher than non-agreement cases. The presence of the leniency program not only increases the amount of the gross penalties, but also the penalties actually paid by the firms, i.e. after accounting for the leniency discounts. Brenner (2009) in his article also finds support for Hypothesis 1 through his respective models previously cited.

Table 5 shows the results obtained for equation 3. Although the LP variable, which indicates if the leniency program helps to reduce the costs of investigation and prosecution, presents a statistically significant coefficient, its sign is contrary to what is expected by Hypothesis 2. This is because the estimation results showed sigma significantly lower than 1, indicating that it is a monotonically increasing monotonous hazard function, that is, the greater the risk of detection and prosecution, the longer the duration of the administrative procedure. 
Table 5 - Model of Equation 3

\begin{tabular}{|c|c|c|c|c|}
\hline \multicolumn{5}{|c|}{ Result of the model estimation: Duration (Weibull), using observations 1-73 } \\
\hline \multicolumn{5}{|c|}{ Dependent variable: DI } \\
\hline \multicolumn{5}{|c|}{ Standard errors based on Hessian } \\
\hline & coefficient & standard error & $\mathrm{z}$ & p-value \\
\hline Const & 0.80076 & 0.109576 & 7.3078 & $2.72 \mathrm{e}-013^{\star * *}$ \\
\hline LP & 0.277271 & 0.0978809 & 2.8327 & $0.00462^{* * *}$ \\
\hline DITCC & 0.132157 & 0.00911632 & 14.4968 & $1.27 \mathrm{e}-047^{* * *}$ \\
\hline DC & 0.0146627 & 0.0165356 & 0.8867 & 0.37522 \\
\hline DC2 & 0.00150761 & 0.000799911 & 1.8847 & $0.05947^{*}$ \\
\hline NF & -0.00349199 & 0.00610727 & -0.5718 & 0.56747 \\
\hline SER & -0.0291338 & 0.0837127 & -0.3480 & 0.72782 \\
\hline IND & -0.00435532 & 0.123514 & -0.0353 & 0.97187 \\
\hline Sigma & 0.200056 & 0.018983 & & \\
\hline Average dep. variable & & & variable & 3.155110 \\
\hline Chi-square(7) & & & alue & $2.65 e-26$ \\
\hline Likelihood log & & & Criteria & 17.71790 \\
\hline Schwarz's Criteria & & & inn's Criteria & 25.93298 \\
\hline $1 /$ sigma $=4.99859(0.4$ & & & & \\
\hline
\end{tabular}

Source: Authors' elaboration.

Considering that the sign of the coefficient of the LP variable is positive, the positive effect under the dependent variable DI is reinforced, contrary to Hypothesis 2. In contrast, Brenner (2009) finds support for Hypothesis 2 in his article through his respective OLS model. For the present study, tests were performed using the exact model used by Brenner (2009); however, the coefficient of the explanatory variable of interest is not statistically significant.

Although CADE signed 54 leniency agreements since the adoption of the program until April 2016 (as in Figure 2), only six administrative proceedings were judged. Considering the scenario of Leniency Program adoption, the average duration of the administrative procedures in which leniency agreements were signed is seven years, while the average time of those that did not have a leniency agreement is 5.44 years. The average duration of administrative procedures until the first CDA is also greater than those without CDA, 6.37 years and 4.6 years, respectively.

In an interview with the newspaper Valor Econômico (2016 apud SENADO, 2016) the then President of CADE Vinícius Carvalho said that the local authority raised a lot of money in payments through agreements with firms that recognized they had committed illegal practices. In 2015 alone, five hundred and twenty eight million BRL were collected. However, the budget of twenty million BRL for the institution was far below their needs. 


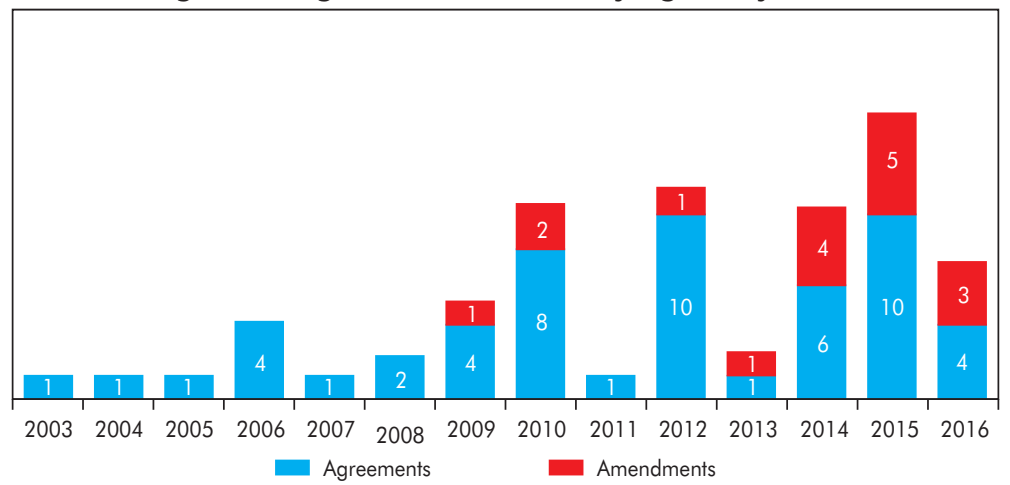

Source: Authors' elaboration based on data from CADE (2016).

According to Carvalho, if CADE had 50 more staff members and 10 million reais more in the budget, it could do more dawn raids, open more investigations and collect almost double what it collects today. Complementarily, he says that:

We have between 80 and 90 staff members responsible for dealing with processes. Portugal, which is ten times smaller than Brazil, has 60. In the European Union, in a case of complex unilateral conduct there are five people just to take care of the case. In Brazil, the same technician who takes care of a big case, involving, for example, Google, has to take care of ten more cases. (JORNAL VALOR ECONÔMICO, 2016 apud SENADO, 2016, our translation)

Although the current situation regarding the technical framework of the antitrust authority may not be a picture of the entire period of CADE activity under review, it may explain in part the fact that an investigation procedure with a leniency agreement will not necessarily have reduced duration according to such agreement.

Besides that, Martinez (2015) points out that Brazilian law requires the signatory of the leniency agreement to identify all employees wishing to sign the agreement together as well as employees of other cartel members, resulting in a large number of people involved, which extends the investigations and prosecutions duration. Perhaps, that is why 54 leniency agreements were signed by April 2016 and only six administrative cases were effectively tried.

Table 6 shows the results obtained for equation 4. According to the equation 4 estimates, support for Hypothesis 3 is found, regarding the duration of the cartels detected after the adoption of the Brazilian Leniency Program. The variable $S R$, which assumes the value 1 when the cartel is extinguished after the introduction of the 
leniency program, presents a statistically significant coefficient, with a respective p-value of 7,43e-05. It also shows a signal compatible with Hypothesis 3 , since the sigma found is significantly lower than 1 , indicating a monotonous increasing hazard function that predicts a direct relationship between the rate of cartel detection and the duration of the cartels in a post-introduction scenario of lenience program. That is, when the dummy variable SR assumes the value 1, the expected duration of the cartels increases.

Brenner (2009) does not find support for Hypothesis 3 through his duration model. The coefficient of his relevance variable (LP-ST) is not significantly different from zero. The author concludes that the leniency program may not be strong enough to have an impact on the stability of cartels or that the stabilizing and destabilizing forces of the leniency program are balanced.

\section{Table 6 - Model of Equation 4}

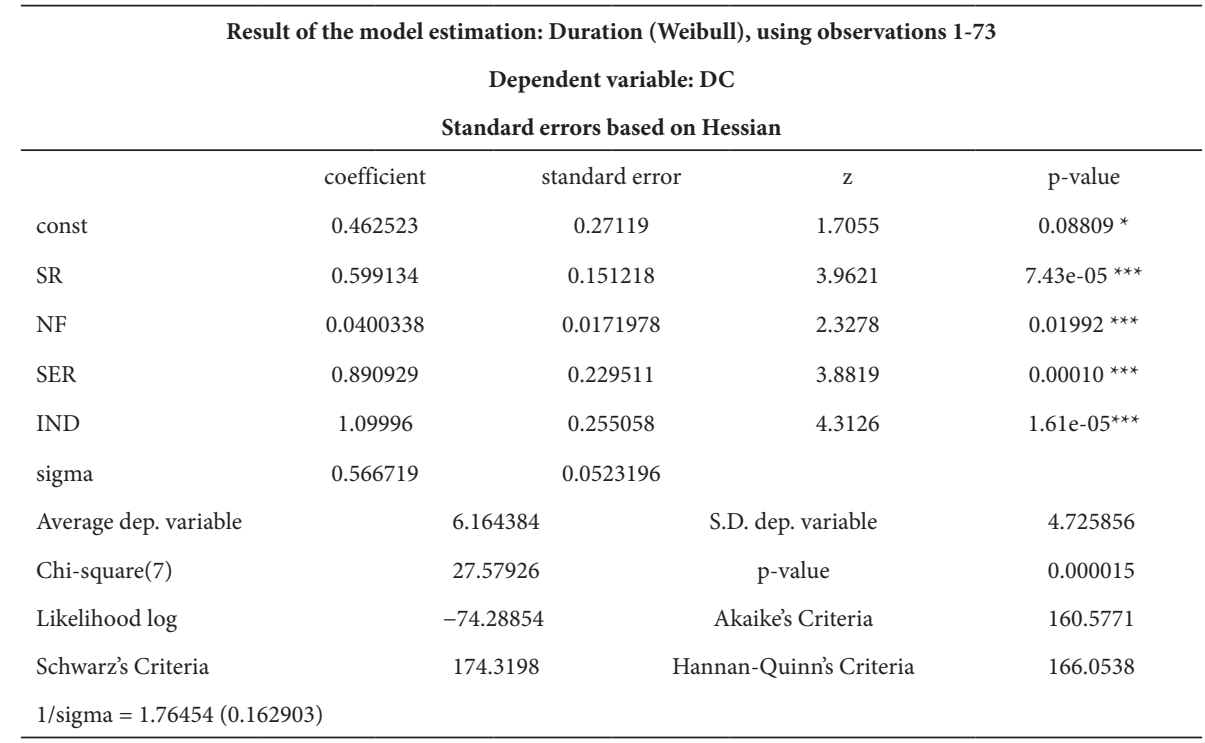

Source: Authors' elaboration.

Figure 3 shows the empirical density of detection frequency over the years that seeks to assess the existence of support for Hypotheses $4 \mathrm{a}$ and $4 \mathrm{~b}$, which consider a temporary increase followed by a long-term decrease in the number of detected cartels indicating that the leniency program increases the detection rate and decreased formation rate. There is no increase in the number of cartels detected immediately after the adoption of the leniency program, or even a decreasing long-term trend of detection below the levels recorded prior to the adoption of the program. A similar result was found by Brenner (2009). 
Figure 3 - Empirical density plot of the detection frequency

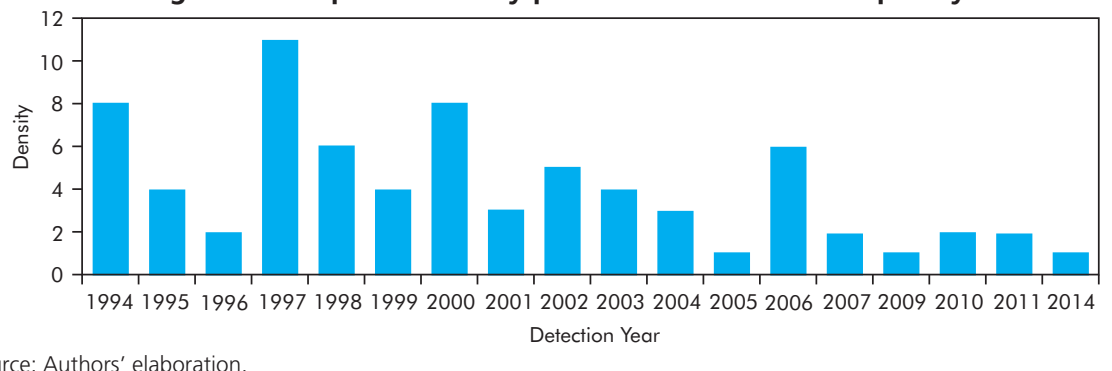

\section{CONCLUSION}

Currently, the leniency program is considered one of the most important instruments in cartel deterrence and is therefore adopted by the main antitrust authorities in the world. Evaluating the effectiveness of this instrument is a very important step to be taken to ensure the success of antitrust policy. The present work sought to empirically evaluate the effectiveness of the Brazilian Leniency Program adopted in the year 2000, using data from cartels detected between 1994 and 2014, which did or did not have leniency agreements entered into with CADE. For this evaluation, we tried to answer the following questions: (i) does the leniency program induce a higher level of revealed information about cartels than the level achieved by traditional methods, and consequently decreases the duration and cost of administrative procedures? (ii) does the leniency program destabilize existing cartels and discourage the emergence of new cartels?

Regarding the first question, the evidences suggest there is a greater level of information revealed on the cartels after the adoption of the leniency program. The level of penalties for administrative proceedings was used as a proxy for disclosed information, since better documented cases can lead to more severe penalties. On the other hand, the evidences do not point to a decrease in the costs of investigation and prosecution, whose proxy used was the duration of administrative proceedings. Possible factors that may influence such results are the lack of a well-designed technical framework, to meet the demands of the antitrust agency, and some requirements of the Brazilian law regarding the leniency agreement that can lead to longer periods of investigation and prosecution.

Regarding the second question, the evidence suggests the leniency program helps to destabilize existing cartels, as the average duration of cartels detected after the adoption of the program increases, a factor indicating that marginal (more unstable) 
cartels are discouraged from maintaining the agreements. As a consequence, the share of more stable cartels in the population of the detected cartels grows. However, the evidence is not sufficient to conclude that the program discourages the emergence of new cartels, according to the hypotheses proposed by Miller (2009).

\section{REFERENCES}

AUBERT, C.; REY, P.; KOVACIC, W. E. The impact of leniency and whistle-blowing programs on cartels. International Journal of Industrial Organization, v. 24, n. 6, p. 1241-1266, 2006.

BRENNER, S. An empirical study of the European corporate leniency program. International Journal of Industrial Organization, v. 27, n. 6, p. 639-645, Mar. 2009.

CADE - CONSELHO ADMINISTRATIVO DE DEFESA ECONÔMICA. Combate a Cartéis e Programa de Leniência. Brasília: CADE, 2009. Available at: <http://www.cade.gov.br/acessoa-informacao/publicacoes-institucionais/documentos-da-antiga-lei/cartilha_leniencia. pdf>. Access on: Jul. 30, 2016.

CADE - CONSELHO ADMINISTRATIVO DE DEFESA ECONÔMICA. Defesa da concorrência no Brasil 50 anos. Brasília: M\&W Comunicação Integrada, 2013.

CADE - CONSELHO ADMINISTRATIVO DE DEFESA ECONÔMICA. Guia Programa de Leniência Antitruste do Cade. Guias do CADE. Brasília: CADE, 2016a. Available at: <http:// www.cade.gov.br/acesso-a-informacao/publicacoes-institucionais/guias_do_Cade/guia_ programa-de-leniencia-do-cade-final.pdf>. Access on: Jun. 02, 2016.

CADE - CONSELHO ADMINISTRATIVO DE DEFESA ECONÔMICA. Guia Termo de Compromisso de Cessação para casos de cartel. Guias do CADE. Brasília: CADE, $2016 \mathrm{~b}$. Available at: <http://www.cade.gov.br/acesso-a-informacao/publicacoes-institucionais/ guias_do_Cade/guia-tcc-versao-final.pdf>. Access on: Jul. 07, 2016.

ELLIS, C.; WILSON, W. Cartels, Price-Fixing, and Corporate Leniency Policy: What Doesn't Kill Us Makes Us Stronger. Eugene: University of Oregon, 2002. Manuscript.

FIDELIS, A. L.; MARTINS, A. A. L. Leniency Programme in Brazil - Recent Experiences and Lessons Learned. Brasília: CADE, 16 mar. 2016. Available at: <http://www.cade.gov.br/ assuntos/programa-de-leniencia/publicacoes-relacionadas-a-acordo-de-leniencia/2016_ ocde_leniency-in-brazil.pdf/view>. Access on: Jun. 20, 2016.

HARRINGTON, J. E.; CHANG, M.-H. Modeling the Birth and Death of Cartels with An Application to Evaluating Competition Policy, Journal of the European Economic Association, v. 7, n. 6, p. 1400-1435, Dec. 2009.

JACQUEMIN, A.; SLADE, M. E. Handbook of Industrial Organization. Nova York: Elsevier, v. I, 1989.

KLEIN, G. Cartel Destabilization and Leniency Programs - Empirical Evidence. Centre for European Economic Research, n. 10-107, Dec. 2010.

MARSHALL, R. C.; MARX, L. M. The economics of collusion: Cartels and bidding rings. Cambridge: MIT Press, 2012. 
MARTINEZ, A. P. Challenges Ahead of Leniency Programmes: The Brazilian Experience. Journal of European Competition Law \& Practice, v. 6, n. 4, p. 260-267, 2015.

MATTOS, C. A revolução do Antitruste no Brasil. São Paulo: Singular, v. 1, 2003.

MILLER, N. H. Strategic Leniency and Cartel Enforcement. American Economic Review, v. 99, n. 3, p. 750-768, Jun. 2009.

MOTTA, M.; POLO, M. Leniency programs and cartel prosecution. International journal of industrial organization, v. 21, n. 3, p. 347-379, 2003.

MOTTA, M.; SALGADO, L. H. Política de concorrência: teoria e prática e sua aplicação no Brasil. 1. ed. Rio de Janeiro: Elsevier, 2015.

OECD - ORGANISATION FOR ECONOMIC CO-OPERATION AND DEVELOPMENT. Report on the Nature and Impact of Hard Core Cartels and Sanctions Against Cartels Under the National Competition Laws. [S.1.] OECD, 2002.

PORTER, M. E. Competitive strategy: Techniques for analyzing industries and competitors. Nova York: Free Press, 1980.

SENADO, 2016. Available at: <http://www2.senado.leg.br/bdsf/bitstream/handle/id/522060/ noticia.html?sequence=1>. Access on: Sep. 18, 2016.

SPAGNOLO, G. Divide et impera: Optimal deterrence mechanisms against cartels and organized crime. Mannheim: University of Mannheim, 2003.

SPAGNOLO, G. Leniency and whistleblowers in antitrust. CEPR Discussion Paper, n. 5794, Aug. 2006.

STIGLER, G. J. A Theory of Oligopoly. The Journal of Political Economy, Chicago, v. 72, p. 44-61, 1964.

TIROLE, J. The theory of industrial organization. Boston: The MIT Press, 1988. 